\title{
From Tribunal to Court: Latest Development of Judicial Protection for Intellectual Property in China*
}

Xiaoqing Feng ${ }^{* *} \&$ Li Wang ${ }^{* * *}$

The judicial protection of IP is the most important and fundamental guarantee for the protection of IP in China. The judicial protection system of IP in China has experienced the development procedure of setting up a special pilot tribunal, "three-hearing-in-one" and a special court. The establishment and operation of IP courts in Beijing, Shanghai, and Guangzhou marks the establishment of the new hearing system for IP dispute in China. The founding and operation of IP courts have an in-depth background. With the rapid development of the economy in China, especially since the entrance of the WTO, there have been more IP cases and they constitute huge challenges for adjudication of IP disputes in China. In this regard, the IP courts is a good way to cope with. The establishment of IP courts will undoubtedly has deeper influence and significance in the judicial protection of IP in China, yet there are also many problems and difficulties to tackle with it.

Keywords: Special Courts, IP Court, Judicial Protection, Three-Hearing-in-One, China

* This paper is supported by the Training Support Program for Outstanding Middle \&Young Teachers, China University of Political Science and Law (CUPL). We would like to express our thanks to Dr. Yang Sun (Associate Professor at CUPL) for his help.

** Vice-Chairman, China IP Law Society (CIPLS); Director \& Professor of Law at the Institute of IP Law of CUPL. Ph.D. (Peking). ORCID: http://oricd.org/0000-0002-5902-7019. The author may be contacted at: fengxiaoqingipr@sina.com / Address: Please provide your postal address for complimentary copies. Institute of Intellectual Property Law, China University of Political Science and Law (CUPL), No.25, Xi Tu Cheng Road, Beijing, 100088, P. R. China.

*** Attorney-at-Law (ZY Partners-Beijing); Executive Editor of Newsletter of IP, CUPL. LL.M. (CUPL). ORCID: http://oricd.org/0000-0001-6727-1997. The author may be contacted at: 295541907@qq.com. /Address: ZY Partners, Kuntai International Plaza, Suite 2606, 12 Chaowai Street, Chaoyang District, Beijing 100020, P. R. China. 


\section{INTRODUCTION}

Judicial protection is the most important form to defend Intellectual Property ("IP") in China. It aims to ensure effective implementation and enforcement of IP through the People's Courts at all levels timely and correctly. ${ }^{1}$ The basic form of judicial protection of IP in China has developed from special tribunal, the pilot of "three-hearing-in-one" ${ }^{2}$ to the special court. The first group of IP courts in China was initiated in 2014. Today, the IP courts have received widespread attention at home and abroad.

This research will explore the theory and practice of China's judicial protection of IP with special references to the IP court. This paper is composed of seven parts including a short Introduction and Conclusion. Part two will analyze the evolution of China's judicial protection system of IP. Part three will examine the background for founding the IP courts in China. Part four will discuss China's court system of IP. Part five will probe into the function and significance of the special courts of IP in China. Part six will focus on the problems for improving the operation of IP courts in China.

\section{The Evolution of China's Judicial ProteCtion OF IP}

\section{A. Background}

China has strengthened the judicial protection of IP following the changing international and domestic situation. First, judicial protection of IP in China complies with the international trend. Today's scientific and technological progress is largely integrated with the economic and social development, as well as every aspect of human life. In this context, the core strategic position of IP in national economic development is displayed. ${ }^{3}$ The protection of IP has come to a post-TRIPs Agreement era, featured by improving the protection level and strengthening the legal measures of enforcement. The Trans-Pacific Partnership Agreement ("TPP") and the Transatlantic Trade and Investment Partnership Agreement ("TTIP") are building higher protection level for IP. In 2011, the AntiCounterfeiting Trade Agreement ("ACTA") was signed, which enhanced and 
implemented legal enforcement for IP as well as a severe fight against piracy and counterfeiting than that of TRIPs Agreement. The IP protection would sometimes cause political and diplomatic friction. In this regard, China is trying to strengthen the judicial protection of IP in practice.

Second, judicial protection of IP is required in order to promote domestic sustainable development. The protection of IP in China has transformed from "being forced to use" to "making use of it" and from "passive transplant" to "positive arrangement." In terms of judicial protection of IP in China, the internal factors and forces are playing more important role. In this course, the imbalanced level between different regions, the incongruity between various social relations and the unsustainable mode of development were exposed. The shortage of resources and environmental pollution indicate that the traditional model of economic development is not sustainable anymore. For sustainable development, the traditional way of development through resource consumption must come to an end in China. Instead, economic development should be more knowledge-based and globalized. IP has increasingly become the strategic resources for national development. Scientific and technological progress and cultural development have become the internal demands for China to construct an innovation-oriented country.

\section{B. The Special Tribunal System for IP Protection in China}

Since the second half of the twentieth century, the hearing system for IP cases has been reformed all over the world. Many countries including the UK, South Korea, Japan, and the US set up either independent courts or special appellate courts to handle IP cases. ${ }^{5}$

China also started to specialize the organization for IP trial. As early as 1993, Beijing Municipal Higher People's Court and Beijing Intermediate People's Court primarily set up the IP tribunal mainly for hearing civil disputes involving IP. In 1994, both Shanghai Higher People's Court and Shanghai Intermediate People's Court established IP tribunals. In 1996, the IP tribunal of the Supreme People's Court came into force. Subsequently, provinces and cities all over the country started to set up IP tribunals. As of today, China has hundreds of IP tribunals (31 higher people's courts + more than 400 intermediate people's court + more than 100 grassroots courts) with more than 3000 judges specialized in IP cases, who 
hear about 100,000 IP cases every year.

\section{The Establishment of IP Courts in China}

In China, recently, IP disputes have outnumbered one hundred thousand pieces every year, largest in the world. As IP cases have become more complicated and the judicial protection system has faced many problems, such as how to guarantee the cultivation and building of the judge team; how to handle the "cycle litigation" of IP cases; how to solve the procrastination and low efficiency in IP infringement litigation; how to solve the non-consistency of criteria; and the issue of "different judgment for the same case." Therefore, Special tribunals for IP have been set up widely in the whole country in order to solve these problems. In practice, China has consequently established specialized IP courts. Since November of 2014 when Beijing, Shanghai, and Guangzhou established IP courts successively, a total of 15,772 IP cases of various types have been heard by the end of December $2015 .{ }^{8}$

\section{Table 1: Development of IP Courts in China}

\begin{tabular}{c|l}
\hline Year & \multicolumn{1}{c}{ Event } \\
\hline 1997 & $\begin{array}{l}\text { Yongshun Cheng, the then deputy chief judge of the IP tribunal under the } \\
\text { Beijing Higher People's Court, firstly proposed the establishment of IP } \\
\text { court. }\end{array}$ \\
\hline 2001 & $\begin{array}{l}\text { At the 4th session of the 9th Chinese People's Political Consultative } \\
\text { Conference, Boming Wu, the then deputy director of National IP Office } \\
\text { ("SIPO"), proposed to establish IP court in China listing the benefits of the } \\
\text { IP court. }\end{array}$ \\
\hline \multirow{2}{*}{2008} & $\begin{array}{l}\text { The "Outline of National IP Strategy" issued by the State Council proposed: } \\
\text { "Studies also need to be done to reasonably centralize jurisdiction over cases } \\
\text { involving patents or other cases of a highly technical nature and to explore } \\
\text { issues on setting up appellate courts for cases involving IP." }\end{array}$ \\
\hline $\begin{array}{l}\text { Paragraph 13 about The Deepening Reform of Sci-tech System of Decision, } \\
\text { of the "Central Committee of the Communist Party of China on Some Major } \\
\text { Issues Concerning Comprehensively Deepening the Reform" explicitly } \\
\text { pointed out: "The use and protection of IP shall be strengthened and the } \\
\text { incentive mechanism for technical innovation shall be improved to establish } \\
\text { IP court." Afterward, Beijing, Shanghai, Guangzhou, Nanjing, Chengdu, } \\
\text { Zhengzhou and other places applied to set up IP courts. }\end{array}$ \\
\hline
\end{tabular}




\begin{tabular}{c|l}
\hline $\begin{array}{c}\text { June } \\
2014\end{array}$ & $\begin{array}{l}\text { The third meeting held by the Leading Group of Comprehensive Deepening } \\
\text { Reform of Central Committee of the Communist Party of China approved } \\
\text { the Plan on Setting up Court for IP. }\end{array}$ \\
\hline $\begin{array}{c}\text { August } \\
2014\end{array}$ & $\begin{array}{l}\text { The 10th session of the 12th National People's Congress Standing } \\
\text { Committee made a decision which was announced in the form of legislation } \\
\text { that, in Beijing, Shanghai and Guangzhou IP courts would be set up. }\end{array}$ \\
\hline $\begin{array}{c}\text { October } \\
2014\end{array}$ & $\begin{array}{l}\text { The Supreme People's Court issued Provisions Regarding the Jurisdiction of } \\
\text { Cases in IP Court in Beijing, Shanghai, and Guangzhou, which elaborated } \\
\text { the jurisdiction of IP court. }\end{array}$ \\
\hline
\end{tabular}

\section{Why China Set up IP Courts?}

\section{A. Practical Grounds}

\section{Large Number of Professional and Complex IP Cases}

Statistics show that the number of IP cases that the people's court at all levels in China handled is 104451 (2012), 100,800 (2013), 133,863 (2014), and 149,238 (2015), respectively. ${ }^{9}$ Each year, hundreds of thousands of IP cases are accepted by the intermediate people's courts and more than one hundred on grassroots people's courts appointed by the Supreme People's Court. However, because of imbalanced economic development, the cases are mainly concentrated in BeijingTianjin-Hebei Region, Yangtze River Delta Economic Zone and the Pearl River Delta Economic Zone.

IP cases differ from common civil cases in terms of complexity. They are combined with private and public rights, technical expertise and civil, criminal and administrative issues. At the same time, along with the development of science and technology, more intellectual achievements of the human race shall be involved in the adjustment with IP law. Therefore, while hearing the trial of the IP cases, they need to have both techniques and IP knowledge to meet the special requirements. Namely, a special judicial organization should be established according to their own characteristics.

When the IP courts were founded in Beijing, Shanghai, and Guangzhou, the trial resources were optimally allocated so that special court practice is 
fully applied in a trial. Article 7 of Decision regarding the Setting up IP Courts in Beijing, Shanghai and Guangzhou specifies: "After three years from the enforcement of this decision, the Supreme People's Court shall report the implementation of the resolution to the Standing Committee of the National People's Congress." It means that the IP courts established in the three places of China should be as empirical units to collect the most representative judgments experience in China before being promoted nationwide, which fit for consideration as to cost and benefit. It can be said that the establishment of the special courts in three places was the right choice considering China's reality and international experience.

\section{Establishment of IP Tribunal}

The first step for China to specialize the hearing of IP cases was to establish special tribunals. Since the 1990s, all the courts with the jurisdiction over IP cases have set up special tribunals. However, those IP tribunals did not match their name because many IP tribunals were just civil tribunals dealing with civil cases involving IP. In some areas, IP tribunals are re-named as "Civil Division Five," which actually abandons the specialty of IP and generalizes them into civil cases, while, in other areas, IP judges used to be transferred to hear general civil cases. Considering the highly technical IP cases, the vagueness of the law and the varying level of judge would result in the non-consistent interpretation and application of laws in practice. The condition that "different judgment, same cases" appears in different courts and districts, which affects the judicial authority. Although a large number of IP tribunals is widely set up, the issues of unifying judgment criteria, improving judicial efficiency, and promoting professional ability of judicial organization still remain unsatisfied.

\section{The Attempt and Promotion of Three-Hearing-in-One Mode}

As IP cases are divided by their natures, they shall be heard by civil, administrative, and criminal tribunals, respectively. Unless the laws are unified, it would result in different outcomes as a consequence of non-consistent identification. ${ }^{10}$ If one tribunal can deal with those IP cases as a whole, it could ensure the identity of different types of cases as well as avoid conflicts and negative impact on judicial authority. There are three aspects as follows. 
The first is the Exploration of the Hearing Mode of "three-hearing-in-one" for IP cases. In 1996, Pudong New Zone People's Court in Shanghai was hearing the case as for registered trademark 'flying eagle' filed by Shanghai Gillette Co. Ltd. It was authorized by Shanghai Municipal Higher People's Court following the Civil, Administrative, and Criminal Procedure Law. The special tribunal for IP heard the case in a unified mode, which initiated the mode of "three-hearing-in One" for IP cases. ${ }^{11}$ In 2009, the Supreme People's Court enacted the "Third Fiveyear Reform Program of the People's Court (2009-13)." It clearly provided that municipalities directly under the central government and large and medium-sized cities should explore and set up comprehensive tribunals for IP cases. ${ }^{12}$ Up until 2015, a total of six higher people's courts, 95 intermediate people's courts, and 104 basic people's courts had carried out the experimental work and developed a variety of trial modes in practice, including the mode of Pudong, Nanshan, Fujian, Wuhan, Chongqing, and Xi'an. ${ }^{13}$

The second is the advantages of the "three-hearing-in-one" mode. It can effectively improve the low efficiency, conflicting judgments, jurisdictional conflicts as well as other problems in hearing IP cases.

In China, according to the Provisions regarding the Division of Hearing Administrative Cases with regard to Approval and Confirmation of Patent and Trademark issued by Supreme People's Court's, the first instance of civil cases involving IP is usually under the jurisdiction of the intermediate people's court. Instead, the first hearing of criminal cases involving IP is usually under the jurisdiction of the grassroots people's court, while the first instance of administrative cases of a trademark and patent caused by approval procedures are usually heard by Beijing Municipal First Intermediate People's Court. This inconsistent distribution of jurisdiction of the three types of cases may result in different judgment for the same case if the case involves civil, criminal or administrative factors at the same time. It leads to different levels of jurisdiction and different courts in charge. As a result, the "three-hearing-in-one" mode is not only beneficial to the internal unification of jurisdiction within the court, but also more conducive to handle the conflicts in communication and job coordination between the same or different level of administrative law enforcement authorities, public safeguard department as well as procuratorial departments so as to rationalize hierarchy. 
Due to the different legal systems with different values within civil, criminal, and administrative litigation procedures, conflicts would happen with each other if IP cases are heard in different tribunals, which may seriously affect judicial authority. Although the judgment of criminal punishment with civil adjudication can meet the requirements of the efficiency of the lawsuit, e.g., the criminal tribunal has, in fact, exceeded its power in dealing with the civil cases. Therefore, the mode "three-hearing-in-one" can overcome the problems such as delay in procedure and inconsistent criteria due to the lack of communication between different tribunals. The collegial panel can make a comprehensive judgment based on civil, criminal and administrative aspects of the case by making full use of legal knowledge so as to develop three-dimensional judicial protection of IP as a whole.

The third is the lack of basis for legitimacy which would happen in the practice of "three-hearing-in-one." The integrated hearings of civil, criminal, and administrative cases involving IP is a breakthrough of the current rigid regulation with regard to the division in acceptance and hearing of cases in civil, criminal, and administrative litigation law. However, it would somehow mess up the territorial and procedural jurisdiction about case hearing. In fact, such judicial reform is as good as a pilot administrative project which reforms the frame of relevant laws of today. ${ }^{14}$

Another concern is the non-consistent pattern in different regions and nonsystematic reform. E.g., 'Pudong mode' as the first pilot has truly realized the goal of combining the hearing of civil, criminal and administrative IP cases in one tribunal. In Fujian Province, however, "two-hearing-in-one" is just carried out, i.e., only IP cases that are civil and administrative are heard in one tribunal, while the criminal part of those cases is still categorized into ordinary criminal cases under the critical jurisdiction. The Xi' an mode is much looser. In the trial of IP cases featured by criminal and administrative, civil judges are introduced to explore "the unity of trial" in IP cases. ${ }^{15}$ Currently, the "three-hearing-in-one" pilot work is mainly practiced by grass-root courts and the intermediate people's court. By the end of 2014, only five higher people's courts practiced the pilot work and even the IP tribunal of the Supreme People's Court trial had not practiced "threehearing-in-one" yet. Accordingly, the hearing for the first instance is conducted by IP tribunal, but that for the second instance is still done by different divisions respectively. As a result of a different starting point of reform, different modes 
are applied by different places. Since unifying the trial and jurisdiction of cases is missing and the reform is not yet fully systematized, the application of consistent criteria of legal enforcement, integration of judicial resources, and improvement of efficiency of hearing does not come into reality in a fundamental sense.

The strategic consideration in setting up IP courts in China is largely deepening the reform in trial mode of "three-hearing-in-one" for IP cases. Basically, IP courts and trial mode of "three-hearing-in-one" are in the pursuit of specialization of a trial. ${ }^{16}$ China has earned sufficient experience to build IP courts by exploring the hearing mode of "three-hearing-in-one."

\section{B. Policy Background}

\section{Implementing the National IP Strategy for Innovation}

Article 45 of Outline of the National IP Strategy stipulates:

Improve the trial system for IP, optimize the allocation of judicial resources and simplify remedy procedures. Studies shall be carried out on establishing special tribunals to handle civil, administrative or criminal cases involving IP. Studies also need to be done to reasonably centralize jurisdiction over cases involving patents or other cases of a highly technical nature. Explore issues on setting up courts of appeal for cases involving IP. Judicial organs for handling cases involving IP need to be further strengthened and well-staffed to improve the handling of cases and enforcement of law.

Action Plan for the In-depth Implementation of National IP Strategy (2014-20) clearly put forward that the in-depth implementation of national IP strategy is an important support and guarantee for comprehensive deepening of reform and an important measure to promote the upgrading of economic structure, strengthening the civil and administrative trial involving IP and creating good environment for innovation. ${ }^{17}$ According to the plan on setting up IP court, building and running of IP courts will be financed and supported. ${ }^{18}$

While implementing the national IP strategy for constructing an innovationoriented country, strengthening the judicial protection for IP is a critical step. In this course, setting up IP court indicates strengthening judicial organizations of IP, optimizing the allocation of judicial resources, and adapting to the specialization as well as centralizing the hearings involving in IP. 


\section{Herald of China's Reform in Judicial System}

The Decision of Deepening the Reform, adopted at the third plenary session of the 18th Central Committee of the Chinese Communist Party, determined the major tasks of constructing the advanced rule of law in China and deepening the reform of the judicial system. Decision of Some Major Issues regarding Comprehensively Advancing the Rule of Law in China, adopted at the fourth plenary session of the 18th Central Committee of the Communist Party of China, has set the building of socialist legal system with Chinese characteristics and the construction of socialist rule of law as the overall goal of promoting the rule of law in China and presented a series of major reform measures in the aspects of scientific legislation, strict enforcement of laws, impartial justice and law-abiding by all nationals. ${ }^{19}$

To implement the above decisions, the Supreme People's Court formulated its Opinion Regarding Comprehensive Deepening of the Reform of the People's Court on February 26, 2015, and implemented it as "the Fourth Five-year Reform Program of the People's Court (2014-18)., ${ }^{20}$ According to this Opinion, one of the Supreme Court's tasks is "to promote the setting up of IP court and establishing and improving the specialized procedures, jurisdiction system and trial rule which conform to the law of hearing IP according to the characteristics and requirements for IP cases." ${ }^{21}$ The Framework Views on Some Issues on Pilot Reform of the Judicial System (hereinafter Framework Opinion) approved at the third meeting of the Leadership of Comprehensive Deepening Reform of Central Committee Group mainly put forward to policy guidance about the following issues:

1. The administrative system eligible for the judges and procurators is different from the management system for ordinary civil servant;

2. A system of post for judges and procurators should be established;

3. The conditions and procedures on which selection and appointment of judges and procurators is based shall be improved and the principle of "placing cadres under party supervision" shall be adhered to and respect should be shown to the rule of justice to ensure the political quality and professional ability of the group;

4. The responsibility system of case handling should be improved and the judicial transparency should be intensified to strengthen the supervision and restriction mechanism;

5. Strengthening the job safeguard system for the judges and prosecutors is appropriate to their legal responsibility; and 
6. The unified management of human resources, finance and material of courts and procuratorate should be promoted below provincial level. ${ }^{22}$

During the establishment of IP court in China, the following aspects have been practiced to meet the requirements of the judicial system reform.

The First is the Management of Judicial Personnel by Classification. It is to divide the staff of courts and procuratorates into judge (or procurator), judicial administrative, judicial assistants, as well as to treat judges (procurators) in a different way from the ordinary civil servants. Establishment of the post system of judges and prosecutors is the ground for managing judicial personnel by classification. ${ }^{23}$ In selecting judges and prosecutors, particularly, the procedure should be open and fair. The entry threshold should be enhanced, as well.

The IP courts are composed of judges, judicial support staffs, and judicial administrative personnel. There are four types of judicial support staff in IP court: judge assistant, technical investigator, court clerk, and judicial police. In IP courts, judge assistant takes the place of an assistant judge. The main responsibilities of judge assistant include: preparing legal materials before hearing; arranging for the evidence exchange; and cross-examining preliminary evidence; clarifying the focus of the dispute; and implementing mediation before hearing under the authorization of court judge. S/he is entitled to participate in the hearing and request the presiding judge to ask questions as an auxiliary right of investigation. In addition, s/he has the right to assist the judge to draft legal documents such as judgment or ruling, etc. ${ }^{24} \mathrm{~A}$ technical investigator is a judicial support staff particular to IP court. His/her main task is to provide technical support and professional advice for judges about the professional and technical issue. ${ }^{25}$

The second is the judge selection system of IP courts. According to the Framework Opinions, the professional ability will be the core element in selecting judges and prosecutors. The selection committee will nominate candidates for judges and prosecutors. The committee will widely employ all types of participants in IP cases so that there are not only experienced judges and prosecutors but also practicing lawyers and senior legal experts. Also, the channels of candidates should be expanded to select the judges and prosecutors with sufficient judicial experience and excellent judicial capability.

On October 28, 2014, the Supreme People's Court issued the Guidance for 
Selection of Judges for IP Courts (trial version). It stipulates the qualifications of the judges for IP courts as follows.

Minimum Level for qualification as senior judge: six years' experience in relevant judicial hearing; bachelor degree or above in Law Major from standard institutions of higher learning; strong ability in presiding court hearing and drafting judgment documents. $^{26}$

Obviously, IP court judges are more highly and strictly demanded than other court judges in specialization and professionalism. ${ }^{27}$

All the eighteen judges in the newly set up Beijing IP Court have been selected from the seventy-one IP judges in three intermediate people's courts in Beijing by the selection committee. The selection committee is also the first judge selection committee nationwide. In the Guangzhou IP Court, the judge selection committee is made up of twenty-five members, including sixteen judges, three law professors, three lawyers, and three other experts of IP. ${ }^{28}$

The third is the post system for judges. The number of judges in IP court is much smaller than other courts. E.g., there are eighteen presiding judges in the Beijing IP Court, ten in the Shanghai IP Court, and ten in the Guangzhou IP Court. Both associate chief judge and assistant judges of tribunals no longer exist so that the presiding judge and collegial panel are dominating the hearing. The presiding judge responsibility system is stressed to create a good atmosphere for judges to exercise the judicial power independently under the law.

As put by Chuang Wang, the vice chief judge of the Supreme People's Court's IP Tribunal, IP court is the important system of judicial protection of IP in China. It is regarded as both the explorer and pioneer of China's reform of the judicial system. Hence, how it works, on the whole, has a significant impact on the future direction of the judicial system of China. ${ }^{29}$ 


\section{IP Court System in China}

\section{A. New System of Jurisdiction over IP Cases}

\section{The Territorial Jurisdiction}

The first instance cases are under the jurisdiction of IP courts in Beijing, Shanghai, and Guangzhou. They mainly include the following three types. The first type covers technical civil and administrative cases such as those of patent, new varieties of plant, layout design of integrated circuit, technical secrets, and computer software. The second type is administrative cases against the administrative behaviors involving copyright, trademark, and unfair competition made by the state council or local people's governments or above. The third type includes civil cases involving recognition of well-known trademark. ${ }^{30}$

\section{The Cross-District Jurisdiction}

The Guangzhou IP Court will have the jurisdiction over civil and administrative cases in the first instance in Guangdong Province involving patent, new plant varieties, layout design of integrated circuit, technical secrets, computer software technology, as well as civil cases involving recognition of well-known trademark. ${ }^{31}$

By the end of 2014, the number of patent in Guangdong was more than 110,000 , accounting for one-sixth of the whole country (No. 1 in China). In 2014, half of the PCT international applications examined by SIPO were from Guangdong Province. Among the top 10 enterprises who owned invention patent in 2014, five enterprises were located in Shenzhen City of Guangdong Province. ${ }^{32}$ In this sense, Guangdong Province may be evaluated as a national leader in ownership, quantity, and quality of IP. Guangzhou is the capital city of the province, which set up IP court with jurisdiction over the province's technical civil and administrative cases. In particular, civil cases involving well-known trademark based on the administrative division is in line with the objective demand for economic development in the Pearl River Delta Economical Region. Also, the exploration of the pilot cross-regional jurisdiction of IP courts in Guangzhou is significant for the reform in the cross-regional jurisdiction of the IP court across divisions in the future. 


\section{The Exclusive Jurisdiction}

Article 5 of the Provision of Jurisdiction provides that the following cases of the first instance will be under an exclusive jurisdiction of the Beijing IP Court:

1. Those against the decision, ruling or approval of relevant patent, trademark, new plant varieties, layout design of integrated circuit and other IP by the department under the State Council;

2. Those against the ruling about compulsory licensing decision and the compulsory licensing fee or compensation decision about the relevant patent, new plant varieties and integrated circuit layout design issued by the departments under the State Council; and

3. Those against other administrative act relating to IP authorization made by the departments under the State Council.

\section{B. The Institutional Setup and Personnel Configuration}

Institutional setup is somewhat different in the three IP courts. The Guangzhou IP Court is divided into tribunal of patent, copyright, trademark, and unfair competition. It also organizes a relatively fixed hearing team of 1 judge, 1 or 2 assistant justice, and 1 court clerk. The presiding judge is unstable to court. Meanwhile, the Beijing IP court falls into five tribunals: filing chamber, hearing tribunal 1 , hearing tribunal 2 , hearing tribunal 3 and hearing supervision tribunal. ${ }^{3{ }^{3}}$ Obviously, there is no difference in terms of case type between the hearing tribunals in the Beijing IP Court. The hearing tribunals of the Beijing IP court only have the chief judge and no associate chief judges. Hence, the hearing team is relatively fixed with 1 core judge, 1 judge assistant, and 1 court clerk. In this regard, the number of management level is reduced. The Shanghai IP Court and the Third Intermediate People's Court of Shanghai are set up based on the original Shanghai Railway Transport Intermediate People's Court. Both share the office but practice under the principle of "judicial independence in the same administrative office. ${ }^{34}$ Namely, the hearing and management of the Shanghai IP Court remain independent, but other tasks will be shared with the Third Intermediate People's Court of Shanghai. Currently, the first and second tribunals are set up for IP cases, and the technical investigation division will be established soon. Other issues including filing, implementing and integrated management are borne by the Third Intermediate People's Court of Shanghai. ${ }^{35}$ 
The number of judges has been reduced. Today, there is no assistant judge and associate chief judges. However, technical investigator and judge assistant are added as judicial support. The staffing shows its characteristics of "precise organization and flat management." ${ }^{36}$

\section{Technical Investigator}

If technical aspect of the case is the point of issue, the judge may entrust a third party to carry out technical identification based on the entrustment of both parties. In this regard, contradictory appraisal report may appear about the same case. It not only brings about the delay of proceedings and lower efficiency but also does harm to the judicial authority of the judge. Moreover, the neutrality and correctness of the previous appraisal may be on the suspicion.

Regarding the technical issue, many countries have technical staffs to assist judges during the trial by the examination. E.g., Japan established the technical investigator and expert committee system on April 1, 2004, for IP cases. ${ }^{37}$ In Korea, the patent court has the position for technical reviewer dispatched by the Korean IP Office who will participate in the hearings of all procedures and provide a written opinion to the judge. Technical reviewer, however, will not be involved in judgment. ${ }^{38}$ The German Federal Patent Court maintains both legal judges and technical judge. The technical judge has a unique position in German court system enjoying the same legal status, rights, and obligations as legal justice. The German Federal Patent Law provides a high standard of qualification for technical judges. In practice, they are usually selected from the technical inspectors of German Patent Office. ${ }^{39}$

In China, the newly set up IP courts have introduced the technical investigator system. Before then, the technical cases often depended on the advice of expert witnesses, judicial identification, or opinions from a technical expert database to consult technical issues. On December 30, 2014, the Supreme People's Court issued the Interim Provisions of Some Issues regarding the Participation of Technical Investigator in Litigation of the IP Courts (hereinafter Interim Provisions). The Interim Provisions provide a total of ten articles describing the scope, job responsibilities and role of technical review opinions about technical cases of technical investigator. They provide technical investigators with a precise guidance to participate in the litigation activities. ${ }^{40}$ 


\section{Positioning of the Technical Investigator}

Article 1 of the Interim Provisions has made it clear that technical investigators are judicial support staff, which means:

Firstly, technical investigators of IP are the staffs of the court, which is different from the auxiliary technical experts invited by both parties of the cases or technical consultants entrusted by courts. Secondly, the technical investigator has no right of hearing and is a judicial support personnel like judge assistant, which is different from the technical judge in the Patent Courts of Germany and other countries. $^{41}$

\section{Responsibilities of Technical Investigator}

Considering the characteristics of IP cases, Article 6 of the Interim Provisions has specified the concrete responsibilities of technical investigator in the litigation. According to the requirements of the judge, the technical investigator will carry out the following duties:

1. By accessing litigation documents and evidence materials, he shall clarify the focus of the technical fact about the dispute;

2. Make suggestions about scope, sequence and methods of the survey of technical facts;

3. Participate in the investigation, inquest and safeguard and present suggestions about the methods, steps, etc.;

4. Participate in inquiry, hearing and court trial;

5. Offer opinions of technical review and attend the review by collegial panel;

6. Assist the judge to organize appraisers and professionals in related technical field to prepare appraisal and advice if necessary; and

7. Perform other related jobs assigned by the judge. ${ }^{42}$

\section{The Legal Force of Technical Review's Opinions}

Article 9 of the Interim Provisions stipulates: "The technical investigator's opinion of technical review can be a reference for the judge to identify technical facts." This means that the opinion of technical review shall not be used as evidence but only serve as the reference for the judge to identify technical facts.

On October 22, 2015, the Beijing IP Court constituted technical investigation office and appointed the first batch of investigators. Statistics show that, after the 
establishment of the technical investigation office, a total of 12 cases involved technical investigators, all of which are patent administrative cases. ${ }^{43}$ The Shanghai IP Court is exploring the establishment of Technical Fact-finding and Identification System which contains technical survey, technical advice, expert jury, technical appraisal. Meanwhile, it has appointed 11 investigators to set up the investigator team. A total of 38 expert advisory activities and 8 expert juries have been carried out in 2015 . $^{44}$

\section{The Role of IP Courts for IP Case Hearing IN CHINA}

\section{A. Unification of Trial and Judicial Organization}

Today, leading IP countries in the world have special provisions for the trial and jurisdictions of IP cases. ${ }^{45}$ This systematic specialization of IP may come from the nature of public welfare and professionalism. ${ }^{46}$ IP entitles monopoly for private entities to meet the social demand and inspire innovative activities within a certain period of time in a certain region. IP also bears the nature of public as well as private right. "Its nature of public welfare requires judicial protection to contain procedural contents which differs from the contents of private rights protection and the judgment in the results should be highly unified." ${ }^{47}$ The technical and professional nature of IP has presented even higher demands for judges. The trial activities, especially the cognizance of facts, usually require that judges have professional knowledge in the field. To satisfy these requirements, the only solution is the unification of specialized way of trial and judicial organization.

Recently, China has set up the first group of three IP courts in Beijing, Shanghai, and Guangzhou. In terms of hearing level, they are all courts of first instance and appellate court in jurisdiction of highly technical civil and administrative cases of the first instance involving patents, new plant varieties, layout design of integrated circuit, technical secrets and computer software. In these cases, technical investigators often assist judges in identifying the facts and administer the highly technical cases collectively. The appeal cases involving copyright, trademark, technology contract, unfair competition, and other appeals will be heard by the IP court uniformly for the sake of judicial efficiency and 
cost. Simultaneously, supervision can also be undertaken on the second trial so as to achieve the goal of unifying judgment standard of the first instance, while considering both efficiency and fairness.

\section{B. IP Protection for Innovative Country}

China already upgraded IP to the prominent status of the national strategy in $2008 .^{48}$ In 2012, the "development strategy driven by innovation" was put forward. ${ }^{49}$ Since China's reform and opening to the outside world, great progress has been made in various social and economic aspects. In the international context, however, IP has become the essential factor for national development and global competition. Therefore, the effective protection of IP has become the key factor for building an innovation-oriented country. ${ }^{50}$ In this course, IP court will improve the enthusiasm of innovators, transformation of workers and users and develop the virtuous cycle of "innovation- transformation-earning-innovation."

\section{Reformation of IP Courts in China}

China is reforming IP courts comprehensively. These include the classified management system of the judge, the judicial support staff, and the administration personnel, together with opening judicial measures, highlighting the position of the presiding judge, and implementing the responsibility system of the presiding judge. In addition, the judges of newly set up IP court are not related to administrative level, which requires the so-called "de-administration of justice" in China. One of the important tasks in the judicial system reforms is to "explore to set up courts across administrative divisions" and build a new litigation pattern to handle the common type of cases in local courts and special cases in "courts across administrative regions." ${ }^{, 51}$ IP courts are under the interregional jurisdiction, especially in Guangzhou. Here, IP courts enjoy the jurisdiction over IP cases across various regions of Guangdong Province.

Some scholars pointed out that the exploration of the IP courts in China is a test in the highly professionalized field in which staff is of distinctive personality. ${ }^{52}$ It is a path to the comprehensive reform of the judicial system. IP courts can apply new measures for the judicial system reform on a higher platform. Hence, a breakthrough can be achieved in the concrete judicial mechanism and lawsuit system. In this sense, it could be a pioneer of whole judicial reforms in China. ${ }^{53}$ 


\section{Respecting and Protecting IP}

As the second largest economy in the world today, China has a long way to go for the IP protection. Considering the massive amounts of IP litigation encountered by Chinese enterprises under the WTO mechanism, non-tariff barriers as well as the memorandum of understanding between China and the US on the IP protection, the international community, to some degree, would mistrust the IP protection in China. In order to be a leading IP power in the world, China should not only own a large number of excellent patents and trademarks but also make efforts to promote cultural boom for IP. China has indeed made tremendous achievements in building IP legal system. In 2013, the third amendment of the Trademark Law of the People's Republic of China was adopted and the fourth modification of Patent Law is going on and the third revision of Copyright Act is in progress. The IP laws got multiple revisions. It would not only comply with the international convention but also in some respects, take the lead in the world. In line with this legislation progress, the judicial ability and proficiency of law enforcement need to be improved. With IP courts, China seems to improve the international image of respecting IP. Also, the IP courts in China would be a good example for judicial specialization in IP for the rest of the world.

\section{The Operation of IP Courts AND ItS COUNTERMEASURES}

\section{A.The Imperfect Job Safeguard for Judges}

Due to the judge post system in IP courts, the number of IP judges has been decreasing dramatically, while that of cases is increasing. It brings huge work load, great responsibility, low salary, limited space for promotion, etc. In the Guangdong IP courts, e.g., only twenty-six judges applied, only eleven passed the review of qualification, ten of whom were finally appointed by judge selection committee of IP court. It was well below forecasts. ${ }^{54}$

Introduction of job safeguard system for judges should be thus speeded up with the improvement of income level in order to build a team of judges and support staff of high quality. At the same time, the channels and space of promotion for young judges and judge assistants should be ensured so that the loss of judicial 
personnel could be precluded in order to truly implement the judicial reform.

\section{B. Disputes Settlement Mechanism of IP Approval and Cycle Litigation}

To a certain extent, the current dispute settlement mechanism of IP approval is not consistent with the final judicial principle for civil disputes as well as the pursuit of litigation economy and efficiency.

The current administrative litigation process of IP cases is, in fact, taking the disputes of approval involving the invalidation of patents and the opposition of trademarks which occurs among clients of equal parties. Consequently, it concerns with the validity of civil rights as administrative litigation. The ruling as to the IP approval is, in essence, the judgment about the effectiveness of the civil rights so that the kernel of the court hearing shall be the dispute of civil rights and interests. Meanwhile, it is a serious waste of resources for the Patent Re-examination Board and Trademark Review and Adjudication Board to be the defendant frequently and respond each case. This trend seriously affects the trial efficiency of the case because even if the two committees make an obviously wrong decision or ruling, the people's court can usually or partially revoke the decision or verdict and the dispute concerning approval of patent and trademark cannot be solved in essence of judicial judgment. ${ }^{55}$ After the revocation by the people's court, the two committees have to make the decision once again. If both parties refuse to obey, they can file a lawsuit against the new decision and hence a litigation cycle forms. ${ }^{56}$

It is common for courts to confirm the effectiveness while handling IP cases. In the US, as the principle of 'judicial final' is working in practice, courts have the power to determine directly the validity of the patent or trademark granted by the administrative authority. ${ }^{57}$ In 2004, by amending the Patent Law, Japan allowed the court to determine the invalidity of the patent in the lawsuit of patent infringement. Although such decision is only effective between the parties concerned, Japan's position decided in lawsuits can be quoted in other cases. In other sense, the invalidity recognition in an individual case may have universal validity. Taiwan's IP Court is also authorized to identify invalidity so that in a civil lawsuit judges may not wait for the decision of administrative process, but straightly determine the validity of the patent or trademark rights. The IP holder can still claim for other rights in litigation. ${ }^{58}$ 
In a national symposium on the performance of IP courts in 2015, the Beijing IP Court proposed to establish the judicial right to change the authorization and approval in administrative cases. ${ }^{59}$ It means that the court can make explicit judgment about whether certain IP in the lawsuit is invalid and whether it can be registered or canceled in order to avoid litigation cycle and protracted disputes.

\section{The Three-Hearing-in-One Mode Not Yet to Realize}

As early as 1996, China began to explore the mode of "three-hearing-in-one" in IP cases. As of 2014, a total of five higher people's courts and ninety-four intermediate people's courts have conducted the pilot "three-hearing-in-one" and found a variety of modes in practice. However, the mode and mechanism thereof have been appealed for by many experts and insiders of IP and finally, have not been implemented in this IP trial reform. The newly established IP courts mainly accept civil and administrative cases of IP and only "two-hearing- in-one" was practiced. The reasons why criminal cases of IP are excluded out of the scope of the IP courts' jurisdiction might be as follows.

One is due to practical demand. From 2012 to 2015, more than one hundred thousand IP cases were received in China and this figure keeps rising each year. The number of criminal cases involving IP is considerably smaller and accounted for not more than 10 percent of the total amount. Compared with the civil cases, the number of administrative cases was much smaller. Between 2012 and 2013, fewer than 3000 administrative cases related to IP were accepted. Although doubled in 2014, it has never exceeded $10,000{ }^{60}$ They have been included in the jurisdiction of IP court mainly because of the different orientation of function of the newly formed IP courts. As the Patent Re-examination Board of China, the Trademark Review and Adjudication Board and State Intellectual Property Office are located in Beijing, the Beijing IP Court will give priority to hearing the patent, trademark and administrative cases involving authorization and approval.

Statistics show the Beijing IP Court accepted 221 cases within a month after establishment, among which 138 were related to patent, and trademark authorization, accounting for 63.1 percent of the total number of cases. ${ }^{61}$ The Guangzhou and Shanghai IP courts focus on the patent infringement cases and other civil cases. Neither accepts patent or trademark cases related to authorization. Considering the vast number of administrative cases in Beijing, the 
requirements will come to centralized jurisdiction and judicial specialization to practice "two-hearing-in-one" in civil and administrative cases. The criminal cases are widely distributed, but only a few are distributed to each court. The Beijing First Intermediate People's Court, e.g., heard only six criminal cases out of the total 10,000 cases in 2013 . $^{62}$

The second reason involves the peculiarity of criminal cases. Compared to civil and administrative cases, it is more difficult to promote the "three-hearingin-one" mode in hearing criminal cases of IP. Because criminal cases would often involve the court, department of public security and procurator, the coordination among these multilateral institutions is highly necessary. Therefore, it is the key to involving criminal cases into the "three-hearing- in-one" mode. ${ }^{63}$ Further, criminal proceedings are quite different from civil and administrative ones. It is thus not yet the right time for criminal cases of IP to be heard by IP court.

Since 1996, the courts in Shanghai have implemented "three-hearing-in-one" mode-unified hearings of civil, criminal, administrative cases involving IP. This practice proved that "the three-hearing-in-one" mode is conducive to unifying legal standard of enforcement, improving judicial efficiency, and strengthening the IP protection. However, the newly established Shanghai IP Court only practices "two-hearing-in-one" mode which combines civil and administrative cases. It is disadvantageous for the hearing mechanism.

The Shanghai IP Court tried to solve this problem in practice. The Shanghai IP Court sends its officers to the Third Shanghai Intermediate People's Court for the hearings of IP criminal cases. The "three-hearing-in-one" mode is actually carried out in the Shanghai IP Court by this way. ${ }^{64}$ If IP court has rich experience, the criminal cases of IP are expected to be brought into the jurisdiction with the "three-hearing-in-one" mode.

\section{Special Appellate Court for IP}

As early as 2008, China already proposed "to set up IP appellate court" in the Outlines of National IP Strategy. ${ }^{65}$ In the Decision on Major Issues concerning Comprehensively Deepening Reforms of 2013, the goal was modified to "explore the founding of IP courts." ${ }^{\text {}, 6}$ It means that the Chinese IP court is not limited to the appellate court on the case-hearing level.

Because of China's courts practice called "second-instance-being-the-final- 
instance system," ${ }^{67}$ the first instance cases at IP court will be appealed to the IP tribunal of the local higher people's court. The court of the first instance is specialized courts, whereas the second instance court is the ordinary court. Meanwhile, the local higher people's court which makes the final decision is still at the local level so that issues like inconsistency of judgment standard and different judgment for similar case remain an issue. Obviously, the previous disadvantages restricting the hearing of IP cases in China still remain unsatisfied

In this context, Prof. Chuntian Liu, Chairman of Chinese IP Law Society ("CIPLS") said that IP appellate courts should be set up and the reform of the judicial organization of IP in China should also stay at the level of 'local team." Instead, he continued, a qualitative change of 'national team' is necessary, otherwise, the reform will just stop at quantitative change and the fundamental problem will remain. ${ }^{69}$ As the establishment of a special court system in China is still on-going, setting up IP courts and practicing trans-regional jurisdiction at the level of intermediate court will give trial experience until the IP appellate court is actually established. ${ }^{70}$

The authors would opine that, on the basis of domestic practical experience, China can refer to the dual level court structure of Unitary Patent Court for Europe and set up a special appellate court for IP in nationwide. In this way, the inconsistent results about infringement on European patent will be greatly improved.

The authors also think that, after setting up the first three IP courts, China can set up more IP courts at the equivalent level to the intermediate people's court and practice trans-regional jurisdiction. Then, an appellate court equivalent to the level of higher people's court could be established in Beijing to guide the national IP courts and unify judgment standard of first-instance. Considering the limited judicial resources and convenience for the appeal of clients, the IP appellate court may set up a detached tribunal in the regions where cases are centralized or adopt the assizes. 


\section{Conclusion}

The establishment of IP court is a landmark of judicial protection of IP in China. ${ }^{71}$ China has determined to strengthen the protection of IP in a global standard for an innovation-oriented country. China's IP court is a mirror showing the latest trend of judicial protection of IP and each specific measure for the judicial system reform of China.

The IP court was established in the period of social transition with both opportunities and challenges. The challenges come from the trial system of IP; comprehensive judicial reform; and economic development of China. ${ }^{72}$ China's IP court will make unique contribution to the perfect IP judicial system with a higher level of judicial protection for IP.

\section{REFERENCES}

1. Xiaoqing Feng, Research on IP Litigation [知识产权诉讼研究] (1997).

2. It means an independent IP tribunal has jurisdiction over civil, administrative and criminal cases of IP. See the concrete analysis in the next parts.

3. Xiaoming Xi, Policies and Ideology of Current Judicial Protection of IP [当前我国知识产权司 法保护的政策与理念], 3 InTELL. PRop. [知识产权] 3-10 (2012).

4. Handong Wu, Evaluation and Reflection of the Legal Construction of IP in China [中国知识 产权法制建设的评价与反思], 1 CHINA LEGAL SCI. [中国法学] 51-68 (2009).

5. Handong Wu, Three-Hearings-in-One: The Special District Mode of Judicial Reform of IP [“三审合一”: 知识产权审判改革的特区模式], DAILY OF PeOple’s Court (Nov. 24, 2011).

6. Xinliang Tao, Some Ideas about the Setting up of IP Court [建立知识产权法院的若干思考], Daily of Rule of Law in Shanghai (July 16, 2014).

7. See Part VI of the Operation of IP Courts and Its Countermeasures and accompanying text.

8. State IP Office of the PRC, The Judicial Protection of IP by Courts in China in 2015, Apr. 22, 2015, available at http://www.sipo.gov.cn/ztzl/ndcs/qgzscqxcz/xwfb/201604/ t20160422_1264240.html (last visited on Aug. 5, 2017).

9. See The Judicial Protection of IP by Courts in China in 2012 [2012年中国法院知识产权司 法保护状况], China Court Website, Apr. 22, 2013, available at http://www.sipo.gov.cn/ wqyz/gndt/201310/t20131025_858974.html; The Judicial Protection of IP by Courts in China in 2013, Apr. 25, 2014, available at http://www.court.gov.cn/zscq/bhcg/201404/ t20140425_195314.html; The Judicial Protection of IP by Courts in China in 2014, Apr. 20, 2015, available at http:/www.court.gov.cn/zixun-xiangqing-14207.html; The Judicial Protection of IP by Courts in China in 2015, Apr. 22, 2015, available at http://www.sipo.gov. cn/ztzl/ndcs/qgzscqxcz/xwfb/201604/t20160422_1264240.html (all last visited on Aug. 5, 
2017).

10. Mianqing Wang, The Three-in-one Hearing Mechanism of IP Court [知识产权法院的 “三审 合一”审判机制], Daily of Rule of Law in Shanghai, Aug. 6, 2014.

11. Xinliang Tao, Some Ideas about the Setting up of IP Court [建立知识产权法院的若干思考], Daily of Rule of Law in Shanghai, July 16, 2014.

12. The Judicial Protection of IP by Courts in China in 2015 [2015年中国法院知识产权司法保 护状况], Apr. 22, 2015, available at http://www.sipo.gov.cn/ztzl/ndcs/qgzscqxcz/xwfb/ 201604/t20160422_1264240.html (last visited on Aug. 5, 2017).

13. Id.

14. Shuzhu Hu, On Establishment of the IP Courts (tribunal): the Rational Thinking of the Judicial Reform of Hearing Involving IP in China [试论知识产权法院（法庭）的建立-对我国 知识产权审判体制改革的理性思考], 4 INTELL. PROP. [知识产权] 37-42 (2010).

15. Xiaojin Zhang, Three-Hearing-in-One: A Research of the Mode Operation for Hearing IP Cases - With the Example of Hearing Tribunal of Beijing IP Court [三审合一: 知识产权案 件审判模式运行研究-以北京市法院知识产权审判庭为例], 82 BEIJING ARB. [北京仲裁] 32-44 (2013).

16. Xuemei Cheng \& Peiyu He, Examination and Reference of European Unified Patent Court, and the Path of Building China's IP Court [欧洲统一专利法院的考查与借鉴-兼论我国知识产 权法院构建的路径], 4 InTELL. Prop. [知识产权] 89-94 (2014).

17. See Action Plan for the In-depth Implementation of National IP Strategy (2014-2020) [深 入实施国家知识产权战略行动计划 (2014-2020年)], XINHUANET, available at http://news. xinhuanet.com/fortune/2015-01/04/c_1113870665.htm (last visited on Aug. 5, 2017).

18. Id. art. 4.

19. Decision of Some Major Issues regarding Comprehensively Advancing the Rule of Law in China [中共中央关于全面推进依法治国若干重大问题的决定], XINHUANET, available at http:// news.xinhuanet.com/politics/2014-10/28/c_1113015330.htm (last visited on Aug. 5, 2017).

20. The Supreme People's Court, Opinion Regarding Comprehensive Deepening of the Reform of the People's Court [最高人民法院关于全面深化人民法院改革的意见], available at http:// www.court.gov.cn/zixun-xiangqing-13520.html (last visited on Aug. 5, 2017).

21. Id.

22. Xianming Zhang, Stick to the Combination of Top-Level Design with Practical Exploration and Proceed with Pilot Reform of Judicial System [坚持顶层设计与实践探索相结合积极稳妥 推进司法体制改革试点工作), DAIRY OF PEOPLE's CourT, Apr. 16, 2014.

23. Nannan Li, Judicial Reform: the Change and Confusion of Judges [司法改革: 法官的改变和 困惑], People.cn, Nov. 4, 2014, available at http://legal.people.com.cn/n/2014/1104/c4251025966822.html (last visited on Aug. 5, 2017).

24. Nianzu Shen, The first IP court in China founded, assistant judge is cancelled [全国首家知识 产权法院成立取消助理审判员], P5W website, Nov. 15, 2014, available at http://www.p5w. net/news/gncj/201411/t20141115_837280.htm (last visited at Aug. 5, 2017).

25. Id.

26. Notice of Supreme People's Court about Guidelines for Selection of Judges for IP Court (trial) [最高人民法院关于印发知识产权法院法官选任工作指导意见 (试行) 的通知], China Court Website, Oct. 28, 2014, available at http://www.chinacourt.org/law/detail/2014/10/id/ 
147979.shtml (last visited on Aug. 5, 2017).

27. Based on the rigid selection conditions and procedures, the average age of judges of Beijing IP Court is 40.2 years and 91 percent of them have master degree or above. By average, they have been engaged in hearing cases of IP for 10 years. In recent five years each of them have handled 438.5 cases related to IP right. The Shanghai IP Court boasts 10 judge of IP averaged 43.6 years of age and 8.4 years' experience in hearing cases of IP by average. See Jingxia Guo \& Yan Zhao, The First IP Court in China is Founded in Beijing [全国首家知 识产权法院在京成立], PeOPLE's Court News [人民法院報], Nov. 7, 2014, at 01, available at http://rmfyb.chinacourt.org/paper/html/2014-11/07/content_90126.htm?div=-1 (last visited on Aug. 5, 2017). See also Xielin Wu, The Director of Shanghai IP Court, Revealed the Operation and Condition of IP Court [上海知识产权法院院长吴偕林发布知识产权法院工作运 行情况], China Court Website, Sept. 9, 2015, available at http://www.court.gov.cn/zixunxiangqing-15368.html (all last visited on Aug. 5, 2017).

28. Chang Liu, Judge Selection based on the Principle of Judicial Reform, Directors of Courts Cannot Be "Judges" (Dec. 26, 2014), The South Weekends Website, available at http:// www.infzm.com/content/106579 (last visited on Aug. 5, 2017).

29. Nianzu Shen, The First IP Court in China is Revealed by the Explorer of China's Reform of the Judicial System [司改探路者解密全国首家知识产权法院], EEO, Nov. 19, 2014, available at http://www.eeo.com.cn/2014/1119/268870.shtml (last visited on Aug. 5, 2017).

30. Provisions of Jurisdiction, art. 1.

31. Id. art. 2.

32. See The Press Conference regarding China's invention, patent authorization and the relevant information [2014年我国发明专利授权及有关情况新闻发布会], SIPO website, available at http://www.sipo.gov.cn/twzb/2014fmzlsqqkfbh (last visited on Aug. 5, 2017).

33. Institutional Setup of Beijing IP Court [北京知识产权法院的机构设置], Baidu.com, available at https://zhidao.baidu.com/question/1241809917006141699.html (last visited on Aug. 5, 2017).

34. The Supreme People's Court, The operation of Shanghai IP Court represented by the Chief Justice $\mathrm{Wu}$ Xielin [上海知识产权法院院长吴偕林发布知识产权法院工作运行情况], available at http://www.court.gov.cn/zixun-xiangqing-15368.html (last visited on Aug. 5, 2017).

35. Id.

36. Id. "precise organization and flat management" [机构精简、扁平化]

37. Zhonglin He, Enlightening and Reference of Overseas Court System of Special IP for China [境外知识产权专门法院制度对我国的启示与借鉴], 11 J.L. APPLICATION [法律适用] 84-8 (2010).

38. Id.

39. Shoukang Guo \& Jian Li, On Specialization of Trial Organization for IP in China: in the Perspective of the German Federal Patent Court [我国知识产权审判组织专门化问题研究-以 德国联邦专利法院为视角], 3 JURIST [法学家] 59-63 (2008).

40. See Interim Provisions of Some Issues Regarding the Participation of Technical Investigator in Litigation of the IP Courts [高人民法院关于知识产权法院技术调查官参与诉讼活动若干问题 的暂行规定], Judicial Protection for IP in China Website, available at http://www.chinaiprlaw. cn/index.php?id=504 (last visited on Aug. 5, 2017).

41. Xiaoming Song, Chuang Wang \& Rong Wu, The Comprehension and Applicability of 
Interim Provisions of Some Issues Regarding the Participation of Technical Investigator in Litigation of the IP Courts [关于知识产权法院技术调查官参与诉讼活动若干问题的暂行规定的 理解与适用], 7 People's JudicAture [人民司法] 32-4 (2015).

42. Interim Provisions, art. 6.

43. Zhichanbao Judicial Statistic Center, Statistic Report about Judicial Protection in Beijing IP Court (2015) [2015知识产权大数据分析报告], Apr. 16, 2016, available at http://www.shuju. net/article/MDAwMDM0O1Dgx.html (last visited on Aug. 5, 2017).

44. Judicial Protection of IP in Shanghai IP Court in 2015 [2015年上海知识产权法院知识产权 司法保护], Zhichanli Website, available at http://www.zhichanli.com/article/29525 (last visited on Aug. 5, 2017).

45. Lihua Yang, Research on the History of Patent Law Of the United States of the AMERICA [美国专利法历史研究] (2012).

46. Xuemei Cheng \& Peiyu He, Examination and Reference of European Unified Patent Court, and the Path of Building China's IP Court [欧洲统一专利法院的考查与借鉴-兼论我国知识产 权法院构建的路径]. 4 InTELL. PROP. [知识产权] 89-94 (2014).

47. Id.

48. See Outline of National IP Strategy [国家知识产权战略纲要], SIPO website, available at http://www.sipo.gov.cn/ztzl/ywzt/zlwzn/xgljt/201306/t20130604_801744.html (last visited on Aug. 5, 2017).

49. See Implement of Development Strategy Driven by Innovation [实施创新驱动发展战略], Renmin website, available at $\mathrm{http} / / /$ theory.people.com.cn/n/2012/1213/c352852-19882832. html (last visited on Aug. 5, 2017).

50. See Outline of the National IP Strategy [国家知识产权纲要], June 10, 2008, available at http://www.gov.cn/Zwgk/2008-06/10/content_1012269.htm (last visited on Aug. 5, 2017).

51. The Supreme People's Court, Opinions on Comprehensive Deepening of Reform of the People's Court - the Fourth Five-year Reform Program of the People's Court (2014-2018) [最高人民法院关于全面深化人民法院改革的意见一人民法院第四个五年改革纲要 (2014-2018)], China Court Website, (Feb. 4, 2015), available at http://www.chinacourt.org/law/detail/ 2015/02/id/148096.shtml (last visited on July 20, 2017).

52. Xiuting Yuan, Vision of IP Court in China and Its Implementation Pat [保证公正司法是设立 知识产权法院的根本目标], 1 SCI.-TECH. \& L. [科技与法律] 22-39 (2015).

53. Id.

54. Yubing Ding, The Director of Beijing IP Court Chi Su: Fine infringers don't dare to infringe IP rights again [北京知识产权法院院长宿迟: 要让侵权人赔到不敢再权], Renmin Website, Dec. 18, 2014, available at http://legal.people.com.cn/n/2014/1218/c188502-26234484.html (last visited on Aug. 5, 2017).

55. PRC Administrative Litigation Law (2017), arts. 70-71.

56. Id.

57. Supra note 49.

58. Jun Xu, Planning and Design of China's IP Court [论我国知识产权法院的规划设计], 1 SCI.TECH. \& L. [科技与法律] 41-60 (2015).

59. See The Supreme People's Court Held the National Symposium on the Performance of IP Courts in China, China Court Website, available at http://www.chinacourt.org/article/ 
detail/2015/04/id/1602417.shtml (last visited on Aug. 5, 2017).

60. See Protection State of IP in China (2012) [2012年中国知识产权保护状况], available at http://www.sipo.gov.cn/gk/zscqbps/201408/t20140812_994380.html; Protection State of IP in China (2013) [2013年中国知识产权保护状况], available at http://www.sipo.gov.cn/gk/ zscqbps/2013zgzscqbhzk.pdf; Protection State of IP in China (2014) [2014年中国知识产权保 护状况], available at http://www.sipo.gov.cn/gk/zscqbps/201506/t20150605_1127345.html; Protection State of IP in China (2015) [2015年中国知识产权保护状况], available at http:// www.sipo.gov.cn/gk/zscqbps/201605/t20160512_1268876.html (all last visited at Aug. 5, 2017).

61. Wenming Zhu, 221 Cases Accepted within 1 Month after Beijing IP Court was Founded [ 北 京知识产权法院成立1个月收案221件], ChinA InTELL. Prop. News [中国知识产权报], Oct. 12, 2014.

62. Nianzu Shen, The First IP Court in China is revealed by the Explorer of China's Reform of the Judicial System, EEO website, Nov. 19, 2014, available at http://www.eeo.com.cn/2014/ 1119/268870.shtml (last visited at July 23, 2017).

63. Qiang Shen, From Three-hearing-in-one to IP Court: Concurrent Discussion about the Mode of Hearing and System Reform of IP [从 “三审合一” 到知识产权专门法院-兼论知识产 权审判模式和体制的改革 [J]. 电子知识产权], 2 EleCtronic InTELl. PROP. [电子知识产权] 83-7 (2010).

64. See The Judicial Protection of Intellectual Property by Courts in China in 2015, Apr. 22, 2015, available at http:/www.sipo.gov.cn/ztzl/ndcs/qgzscqxcz/xwfb/201604/t20160422_ 1264240.html (last visited on Aug. 5, 2017).

65. Supra note 11.

66. Supra note 12.

67. The second instance would be the final, which is “两审终审制” in Chinese.

68. See New Property System Should Be Established: From Technology Fight to Copyright Fight [从技术争夺到版权争夺需建立新财产制度], NBD Website [每经网], Sept. 18, 2014, available at http://www.nbd.com.cn/articles/2014-09-18/864125.html (last visited on Aug. 5, 2017).

69. Id.

70. Supra note 25.

71. Supra note 33.

72. Xiaomao Wei, IP Court: Milestone in Protection of IP in China [知识产权法院: 中国知识产 权保护里程碑], SIPO Website, available at http://www.sipo.gov.cn/zscqgz/2009/201310/ t20131024_846801.html (last visited on Aug. 5, 2017). 